\title{
A ABSTRATIVIZAÇÃO DO CONTROLE DIFUSO DE CONSTITUCIONALIDADE NO ÂMBITO DO STF E A (IN)CONSTITUCIONALIDADE DOS ARTS. 525, §12, E 535, §5, DO CÓDIGO DE PROCESSO CIVIL DE 2015
}

\author{
Amaro Bandeira de Araújo Junior ${ }^{123}$ \\ Recebido em: 30/03/2019 \\ Aprovado em: 18/09/2019
}

\begin{abstract}
RESUMO
Os novos influxos relativos à abstrativização do controle difuso de constitucionalidade na jurisprudência do Supremo Tribunal Federal aliados aos dispositivos inseridos no novo Código de Processo Civil, em especial a norma insculpida no art. 525, §12, revelam uma força normativa desproporcional legalmente fixada aos precedentes judiciais oriundos da Corte Constitucional brasileira que podem levar à violação das garantias constitucionais processuais. O presente trabalho intenta analisar a inconstitucionalidade do novel dispositivo processual, ao mesmo tempo em que busca realizar uma análise sobre o espectro possível de limitações hermenêuticas, para além daqueles tradicionalmente aplicados, que podem ser utilizadas para um controle racional mínimo dos fundamentos dos precedentes judiciais vinculantes oriundos das decisões tomadas em controle difuso de constitucionalidade pelo STF.
\end{abstract}

Palavras-Chave: Abstrativização. Controle difuso. Constitucionalidade. Garantias processuais. Execução. Hermenêutica. Coisa julgada.

\section{INTRODUÇÃO}

A partir das alterações constitucionais e infraconstitucionais engendradas nos últimos anos, mormente no âmbito da constitucionalização do processo civil pátrio, o Supremo Tribunal Federal passou a editar verdadeiras normas gerais, abstratas e vinculantes, a partir do julgamento de casos concretos, em especial com o advento do Código de Processo Civil

\footnotetext{
${ }^{123}$ Bacharel em Direito pela Universidade Potiguar. Advogado. Especialista em Direito Tributário pela Universidade Federal do Rio Grande do Norte. Especialista em Direito Administrativo pela Pontifícia Universidade Católica de Minas Gerais. Mestrando em Direito Constitucional pela Universidade Federal do Rio Grande do Norte.
} 
brasileiro de 2015, que entrou em vigor em 18 de março de 2016, no que a doutrina veio a denominar de decisões manipuladoras ou normativas do controle de constitucionalidade.

Dentre as hipóteses apresentadas pelo CPC/2015 sobre precedentes judiciais oriundos da Suprema Corte brasileira que vinculam os demais órgãos jurisdicionais, a norma inserida no art. $525, \S 12$, também reproduzida no art. $535, \S 5^{\circ}$, coloca-se como um importante objeto de estudo, visto que incluiu expressamente a possibilidade da desconstituição ou ineficácia da coisa julgada inconstitucional, tema esse que vinha sendo debatido pela doutrina e jurisprudência na vigência do Código Processual anterior.

Aliás, a referida norma já existia - embora com uma abrangência mais restrita - no Código de Processo Civil de 1973, prevista nos arts. 475-L e 741.

Em que pese estar displicentemente inserida como um dos meios de defesa do executado na fase do cumprimento de sentença, a norma pode passar despercebida, mas trouxe profundas consequências práticas sobre o que se concebe como segurança jurídica proveniente das decisões judiciais.

É que um dos fundamentos basilares para aqueles que litigam judicialmente em um Estado Democrático Constitucional de Direito é um mínimo de segurança jurídica de que o que restar decidido pelo Órgão julgador poderá ganhar ares de definitividade, com a coisa julgada, após o escoamento de todos os prazos recursais. Não por acaso, como sabido, a coisa julgada é alçada à categoria dos direitos e garantias fundamentais da República, no art. $5^{\circ}$, inciso XXXVI, da Constituição de 1988.

Afinal de contas, se houve todo o demorado processo judicial, com todos os recursos, manobras e artifícios existentes, com um direito reconhecido por lei e com a confirmação desse direito declarado pelo Juiz competente, o mínimo que se espera é que tal direito reconhecido por Lei e pelo Estado-Juiz possa ser validamente executado e usufruído pelo cidadão.

Conforme os ensinamentos de Enrico Túlio Liebman, a "coisa julgada é a imutabilidade do comando emergente de uma sentença" ${ }^{224}$. Segundo ele, a imutabilidade da sentença consiste na sua existência formal e ainda nos efeitos dela provenientes.

A coisa julgada se qualifica na órbita da dupla consequência dos efeitos sentenciais irrecorríveis, quais sejam, a imutabilidade e coercibilidade.

A proteção constitucional à coisa julgada possui tanta intensidade que nem mesmo um ato estatal consensual dos representantes democráticos do povo, por meio de Lei em sentido

\footnotetext{
${ }^{124}$ LIEBMAN, Enrico Tulio. "Eficácia e Autoridade da Sentença”, p. 53, item n. 16, nota de rodapé, tradução de Alfredo Buzaid/Benvindo Aires, 1945, Forense.
} 
estrito ou, até mesmo, uma Emenda Constitucional, pode ferir tal atributo das sentenças proferidas pelo Estado-Juiz, de modo a conferir estabilidade à solução dos conflitos, imprimindo confiança e segurança jurídica aos que submetem suas pretensões ao Poder Judiciário.

Todavia, na contramão dessa segurança jurídica, as referidas normas processuais apresentam a inusitada possibilidade de que o executado, em sede de cumprimento de sentença, possa arguir a inexigibilidade de título executivo judicial, ou ingressar com ação rescisória, na hipótese em que a Sentença exequenda esteja fundada em norma declarada inconstitucional pelo Supremo Tribunal Federal ou fundada em aplicação ou interpretação da lei ou do ato normativo tido pelo Supremo Tribunal Federal como incompatível com a Constituição Federal em controle de constitucionalidade concentrado ou difuso.

$\mathrm{O}$ detalhe trazido pela norma adjetiva intensifica a tendência de abstrativização do controle incider tantum de constitucionalidade existente nas Decisões da Corte Constitucional brasileira, permitindo ope legis que o precedente do Supremo Tribunal Federal no controle difuso de constitucionalidade como prejudicial de mérito, em sede de um simples e isolado recurso extraordinário, por exemplo, vincule e permita a desconstituição de decisões judiciais, inclusive, transitadas em julgado, em todo o país, sem que haja as garantias constitucionais existentes no processo objetivo de controle abstrato.

Não é novidade para ninguém a existência dos efeitos erga omnes e ex tunc advindos da declaração de inconstitucionalidade em decisões tomadas em sede de controle abstrato de constitucionalidade, sendo essa, talvez, a característica que defina com maior clareza tal instituto desde os seus primórdios, mas o que se questiona, e esse é o objeto de estudo do presente trabalho, é a ampliação desses mesmos efeitos para o controle concentrado exercido pelo Supremo Tribunal Federal em sede de procedimento de cumprimento de sentença no âmbito do processo civil.

Frise-se que os efeitos erga omnes que exsurgem de decisões do STF proferidas em sede de controle abstrato das normas, em processo objetivo, possuem regras claras e objetivas de debates e verificação, já se levando em consideração a natureza amplíssima da decisão que poderá afetar todo o ordenamento jurídico nacional. Por outro lado, as decisões tomadas pelo STF no controle difuso, que possui natureza de processo subjetivo, de fato não está devidamente aparelhada para a geração de efeitos erga omnes, porquanto não possui os mecanismos atinentes aos processos objetivos de controle de constitucionalidade.

Nesse contexto, as normas inseridas nos arts. 525, $\$ 12$, e 535, $\S 5^{\circ}$, do Código de Processo Civil de 2015, trazem à luz o necessário debate acerca dos contornos hermenêuticos 
a que devem estar adstritos os precedentes judiciais vinculantes, porquanto a criação normativa pelo Supremo e a irradiação da aplicação interpretativa para todo o país, a partir de um caso concreto, sem que tenha havido o contraditório dos milhões de jurisdicionados atingidos, gera a necessidade da verificação prévia dos pressupostos fundantes dos precedentes, a fim de que haja uma higidez não apenas das conclusões, mas principalmente dos fundamentos de onde se originam as decisões judiciais, permitindo que haja uma lógica e coerência no sistema constitucional.

O presente trabalho propõe-se a debater sobre o citado dispositivo processual, analisando inicialmente as consequências práticas, a gênese da norma e os aspectos hermenêuticos que envolvem a apreciação dos precedentes judiciais vinculantes, estudar a necessária higidez metodológica das bases fundantes dos precedentes, por fim, busca explicitar as razões acerca da inconstitucionalidade material da regra inserida no novo Código de Processo Civil em contraponto ao que restou decidido pelo Supremo Tribunal Federal no Recurso Extraordinário 611.503, que julgou pela Constitucionalidade dos dispositivos processuais em questão.

\section{A RELATIVIZAÇÃO DA COISA JULGADA: BREVE HISTÓRICO}

Não é de hoje que os juristas debatem quanto à relativização da coisa julgada, quando essa afronta as normas constitucionais, na medida em que, para parcela da doutrina, a coisa julgada oriunda de sentença violadora da norma constitucional já nasce inválida, de modo que deve sim ser extirpada do sistema, assim como as normas que subsidiaram a decisão jurisdicional.

De forma atípica, sem previsão expressa na lei, a doutrina e a jurisprudência desenvolveram duas categorias de relativização da coisa julgada: a) a coisa julgada inconstitucional e; b) coisa julgada injusta inconstitucional.

$\mathrm{Na}$ categoria da coisa julgada inconstitucional, busca-se o afastamento da imutabilidade da sentença quando essa se basear em lei ou ato normativo declarado inconstitucional pelo Supremo Tribunal Federal, enquanto que a coisa julgada injusta inconstitucional seria aquela em que o caráter imutável da sentença irrecorrível deveria ser relativizado quando tais decisões gerem grande injustiça, violando claramente valores constitucionais basilares do Estado de Direito. 
No Código de Processo Civil de 1973, nos arts. 475-L e 741, bem como no art. 884, $\S 5^{\circ}$, o ordenamento pátrio positivou tal instituto, fixando:

Código de Processo Civil de 1973:

Art. 475-L. A impugnação somente poderá versar sobre:

$\S 1$ o Para efeito do disposto no inciso II do caput deste artigo, considera-se também inexigível o título judicial fundado em lei ou ato normativo declarados inconstitucionais pelo Supremo Tribunal Federal, ou fundado em aplicação ou interpretação da lei ou ato normativo tidas pelo Supremo Tribunal Federal como incompatíveis com a Constituição Federal.

Art. 741. Na execução contra a Fazenda Pública, os embargos só poderão versar sobre:

Parágrafo único. Para efeito do disposto no inciso II do caput deste artigo, considera-se também inexigível o título judicial fundado em lei ou ato normativo declarados inconstitucionais pelo Supremo Tribunal Federal, ou fundado em aplicação ou interpretação da lei ou ato normativo tidas pelo Supremo Tribunal Federal como incompatíveis com a Constituição Federal.

Consolidação das Leis do Trabalho:

Art. $884[\ldots]$

$\$ 5^{\circ}$ Considera-se inexigível o título judicial fundado em lei ou ato normativo declarados inconstitucionais pelo Supremo Tribunal Federal ou em aplicação ou interpretação tidas por incompatíveis com a Constituição Federal.

Todavia, sempre pairou a polêmica quanto à forma de aplicação da coisa julgada inconstitucional, mormente em face da segurança jurídica relacionada às decisões do STF tomadas em controle difuso de constitucionalidade, uma vez que os citados dispositivos do Código de Processo Civil revogado e também da CLT não deixavam claro se sua aplicação se destinava tanto às declarações de constitucionalidade em sede de controle concentrado quanto às decisões tomadas no controle difuso.

Pela lógica do sistema constitucional vigente, como sabido, as decisões do Supremo Tribunal Federal tomadas em sede de controle difuso não possuíam força de precedente vinculante erga omnes e efeitos ex tunc - qualidades essas que estavam adstritas às decisões oriundas do processo objetivo de constitucionalidade (art. 102, §2 $2^{\circ}$, da CF/1988) -, dependendo condicionalmente de uma Resolução do Senado da República (art. 52, X, da CF/1988) para que a lei tida como inconstitucional em Recurso Extraordinário deixasse de vincular apenas as partes naquele processo subjetivo subjacente e passasse a vincular todos os demais processos no território nacional com a suspensão da norma declarada inconstitucional.

Ocorre que começou a surgir uma corrente de abstrativização do controle difuso no âmbito do STF, especialmente capitaneada pelo Ministro Gilmar Mendes, que passou a considerar que, mesmo em sede de controle concreto de constitucionalidade, os Acórdãos do STF possuíam força normativa como precedentes vinculantes e efeitos ex tunc, de modo que 
decidiram os Ministros - numa autêntica viragem solipsista - que as suas decisões, ainda que tomadas em processo subjetivo, não necessitariam da Resolução do Senado para surtirem efeitos erga omnes e ex tunc.

Ocorre que o art. 52, X, da Constituição de 1988, é claro justamente em sentido contrário, de que as decisões do STF necessitariam sim da chancela democrática dos representantes dos Estados da República para surtirem efeitos de maneira geral, com um comando deôntico fechado, não permitindo qualquer outra intepretação.

A solução encontrada pela Corte Suprema para esse impasse - já que não havia abertura para uma intepretação diversa do art. 52, X - foi a de alterar o próprio dispositivo constitucional, nos autos das ADIs 3406/RJ e 3470/RJ, de relatoria da Ministra Rosa Weber, declarando que, na ótica dos ministros, tal norma constitucional sofreu uma "alteração informal", qual seja, uma mutação constitucional, passando a ser tido que a competência constitucional do Senado da República nessa hipótese seria apenas a de divulgar à nação a decisão do STF, relegando aquela Casa Legislativa, data venia, à mera função de relações públicas do Supremo Tribunal Federal, em questionável manobra para aumentar o próprio Poder normativo do STF.

Assim, a partir dessas decisões polêmicas do STF, foram concretizadas as aspirações da Corte Suprema pela abstrativização do controle difuso de constitucionalidade, aspirações essas que foram definitivamente positivadas com a inserção da redação dos arts. 525, §12, 535, $§ 5^{\circ}$, do Código de Processo Civil de 2015, transformando completamente os efeitos das decisões da Corte Constitucional tomadas na análise de casos concretos, de modo que, na prática, foram extintas as diferenças de efeitos das decisões, no âmbito do STF, quanto ao controle difuso concreto ou abstrato de constitucionalidade sem, contudo, alterar os procedimentos objetivos e subjetivos, que permanecem distintos, acarretando, como veremos, sérias inseguranças jurídicas ao sistema jurídico nacional.

\section{A PROBLEMÁtiCA DOS ARTS. 525, §12, E 535, §5, DO CPC/2015 E O PRINCÍPIO CONSTITUCIONAL DA SEGURANÇA JURÍDICA}

Para situar o leitor sobre a problemática envolvida nos dispositivos em análise, consideremos, desde já, a seguinte situação hipotética.

No Brasil, as ações judiciais contra a Fazenda Pública são tradicionalmente demoradas, de modo que muitas vezes somente os herdeiros do autor da demanda é que 
chegam ao fim da lide. O jurisdicionado acaba por permanecer durante décadas litigando contra o Poder Público, mormente em face das prerrogativas processuais dos órgãos públicos, como os prazos em dobro, duplo grau obrigatório, dentre outros.

Imagine-se que após décadas litigando contra a Fazenda Pública, o autor de uma demanda em que se busca a condenação de um órgão público na obrigação de pagar, finalmente tem o trânsito em julgado da decisão favorável, na esteira de milhares de outras decisões judiciais Brasil afora que confirmaram de forma pacífica o direito autoral, depois de passar anos despendendo valores com advogados, perícias, deslocamentos, contadores, etc.

Após o trânsito em julgado, é emitido o competente Instrumento de Precatório para o pagamento dos valores, sendo então incluído na fila de precatórios do respectivo órgão público que, geralmente, está com um atraso de vários anos nos pagamentos. Depois de décadas aguardando o pagamento do precatório, já no fim da vida, o autor finalmente é intimado para receber o valor que lhe é de direito em face do citado precatório.

Ocorre que, assim como o autor da ação, milhares de outras pessoas ingressaram com demanda se baseando na mesma norma, e em apenas uma dessas ações, em outro Estado da Federação - sem que o autor, em nosso exemplo, tivesse conhecimento da ação - houve um Recurso Extraordinário para o Supremo Tribunal Federal que, com base naquele caso concreto específico, declarou incidentalmente inconstitucional a norma em que se baseara o direito do autor.

A partir dessa nova Decisão do STF em sede de controle de constitucionalidade difuso, a Fazenda Pública ingressa com uma ação rescisória no prazo de 2 anos, com fulcro no art. 535, §5 , do CPC/2015 e o autor da demanda é surpreendido, após muitos anos do trânsito em julgado da sentença, com a sua desconstituição e o cancelamento do precatório, perdendo, assim, todos os recursos e tempo investidos no citado processo, sem ter, ao menos, a chance de se manifestar na demanda específica em que se deu a declaração de inconstitucionalidade da norma.

Essa situação hipotética - e absurda - é o que pode ocorrer com milhares de casos no Brasil, com o advento dos arts. 525, §12, e 535, §5 , do CPC/2015, que atribuiu efeitos erga omnes e ex tunc a decisões do Supremo Tribunal Federal em controle difuso de constitucionalidade, fixando de vez a abstrativização do controle incidental de constitucionalidade no direito pátrio.

Vejamos a redação dos dispositivos do CPC/2015: 
Art. 525. Transcorrido o prazo previsto no art. 523 sem o pagamento voluntário, inicia-se o prazo de 15 (quinze) dias para que o executado, independentemente de penhora ou nova intimação, apresente, nos próprios autos, sua impugnação.

$[\ldots]$

$\S 12$. Para efeito do disposto no inciso III do $§ 1$ o deste artigo, considera-se também inexigível a obrigação reconhecida em título executivo judicial fundado em lei ou ato normativo considerado inconstitucional pelo Supremo Tribunal Federal, ou fundado em aplicação ou interpretação da lei ou do ato normativo tido pelo Supremo Tribunal Federal como incompatível com a Constituição Federal, em controle de constitucionalidade concentrado ou difuso.

Art. 535. A Fazenda Pública será intimada na pessoa de seu representante judicial, por carga, remessa ou meio eletrônico, para, querendo, no prazo de 30 (trinta) dias e nos próprios autos, impugnar a execução, podendo arguir:

$[\ldots]$

III - inexequibilidade do título ou inexigibilidade da obrigação;

§ 5o Para efeito do disposto no inciso III do caput deste artigo, considera-se também inexigível a obrigação reconhecida em título executivo judicial fundado em lei ou ato normativo considerado inconstitucional pelo Supremo Tribunal Federal, ou fundado em aplicação ou interpretação da lei ou do ato normativo tido pelo Supremo Tribunal Federal como incompatível com a Constituição Federal, em controle de constitucionalidade concentrado ou difuso.

Da leitura dos dispositivos, é perceptível a preocupação do legislador em incluir, de forma redundante, a mesma norma em dois artigos diversos do CPC/2015 - assim como fizera nos arts. 741 e $\$ 1^{\circ}$, do art. 475-L do CPC/1973 -, incluindo inicialmente no art. 525, $\S 12$, a possibilidade da desconstituição do título executivo no bojo do cumprimento de sentença "comum" e, depois, utilizando-se da mesma redação para o cumprimento de sentença contra a Fazenda Pública, no art. 535, §5º já prevendo a possibilidade de questionamentos quanto à aplicabilidade da citada sistemática aos procedimentos de cumprimento de sentença contra a Fazenda Pública.

Destaque-se que as principais alterações entre o disposto no CPC de 1973 e o CPC de 2015 foram a expressa previsão de que o prazo da ação rescisória (2 anos) conta-se da decisão do STF que declarar a norma inconstitucional, bem como de que a decisão paradigma de onde exsurge a inexigibilidade do título executivo judicial pode ser tomada em controle difuso de constitucionalidade.

Assim, não importa se o prazo da ação rescisória do processo originário já se encerrou, é possível que haja a desconstituição da coisa julgada ad eternum, inclusive, em controle difuso de constitucionalidade, dependendo apenas de que haja uma nova decisão do STF declarando a norma inconstitucional em sede de um mero processo individual.

Saliente-se que, conforme fixado na Constituição de 1988, art. $5^{\circ}$, XXXVI, a Lei não prejudicará a coisa julgada, de modo que é de ser defendido que tais novidades do Código de Processo Civil - em especial a inclusão da possibilidade da propositura da ação rescisória a partir da data da Decisão do STF - somente poderão valer para os processos propostos após a 
entrada em vigor do novo Código, não afetando os processos cujas sentenças transitaram em julgado antes do dia 18 de março de 2016, data em que entrou em vigor o Novo Código Processual brasileiro.

Ressalte-se que os citados dispositivos processuais foram causa de muitas polêmicas no projeto de lei que originou o Novo Código de Processo Civil brasileiro de 2015, em especial no que tange à ampliação dos efeitos da declaração de inconstitucionalidade tomada em controle concreto.

Aliás, o próprio parecer do Senado Federal na tramitação do projeto do novo Código de Processo Civil já buscava excluir da norma a sua aplicação em relação ao controle difuso de constitucionalidade, a fim de privilegiar os contornos constitucionais do controle concentrado, no Tópico 2.3.2.160, in verbis:

\begin{abstract}
Em prestígio ao controle concentrado de constitucionalidade e à abrangência de seus efeitos, devem-se rejeitar o $\$ 10$ do art. 539 do SCD e o $\$ 5^{\circ}$ do art. 549 do SCD, para restabelecer os seus correspondentes no PLS, com um ajuste meramente de redação útil a sua clareza, qual seja, a subdivisão em incisos. Por essa razão, não se acolhe a sugestão contida no Ofício 101/SGCS/AGU no sentido da manutenção do controle difuso de constitucionalidade como suficiente para configurar como inconstitucional e inexigível um título executivo ${ }^{125}$.
\end{abstract}

Esse entendimento exposto na justificativa constante da redação original do Projeto de Lei do CPC/2015 é o mais coerente com o que se expressa na Constituição de 1988, porquanto reafirma que a configuração de inconstitucionalidade de um título executivo judicial somente poderia ocorrer com a decisão do STF em sede de controle abstrato, em processo objetivo, em que existe um debate mais adequado e análise abrangente de suas consequências para o sistema jurídico nacional.

Ademais, essa redação do Projeto de Lei preservava a competência constitucionalmente deferida ao Senado para suspender no todo ou em parte lei declarada inconstitucional em decisão definitiva do Supremo Tribunal Federal, conforme insculpido no art. 52, X, da Constituição de 1988.

Tal redação também estava coerente com a Lei 9.868/1999, que regula o procedimento das Ações Diretas de Inconstitucionalidade, limitando no $\$ 2^{\circ}$ do art. 102, cumulado com o

\footnotetext{
${ }^{125}$ BRASIL. Senado Federal. Parecer $\mathbf{n}^{\mathbf{0}}$ 1.624, de 2010. Da Comissão Temporária da Reforma do Código de Processo Civil, sobre o Projeto de Lei do Senado n ${ }^{\circ} 166$, de 2010, que dispõe sobre a reforma do Código de Processo Civil, e proposições anexadas. Diário do Senado Federal: Brasília, DF, 7 dez. 2010. Disponível em: https://legis.senado.leg.br/sdleg-getter/documento?dm=4550666\&ts=1553282790199\&disposition=inline. Acesso em: 11 jul. 2019.
} 
parágrafo único do art. 28, o efeito vinculante das decisões tomadas pelo STF somente ao julgamento em controle concentrado.

Todavia, atendendo aos apelos da Advocacia-Geral da União e de alguns membros do Supremo Tribunal Federal, o Projeto de Lei foi modificado, por meio de um destaque do Senador Eduardo Braga, a fim de manter a redação que havia sido aprovada na Câmara dos Deputados, no sentido de incluir as Decisões do STF em controle difuso de constitucionalidade como causa de inexigibilidade ou de rescisão das sentenças judiciais em todo o território nacional.

Ocorre que o texto que restou positivado no CPC/2015 acabou por vulnerar o princípio constitucional da segurança jurídica, na medida em que permitiu a relativização desproporcional da garantia constitucional da coisa julgada, facilitando em demasia a desconstituição - para alguns, ineficácia - da decisão judicial.

Nesse contexto, Liebman bem leciona quanto à abrangência do principio da coisa julgada:

[...] se uma questão pudesse ser discutida no processo, mas de fato não o foi, também a ela se estende, não obstante, a coisa julgada, no sentido de que aquela questão não poderia ser utilizada para negar ou contestar o resultado a que se chegou naquele processo. Por exemplo, o réu não opôs uma série de deduções defensivas que teria podido opor, e foi condenado. Não poderá ele valer-se daquelas deduções para contestar a coisa julgada. A finalidade prática do instituto exige que a coisa julgada permaneça firme, embora a discussão das questões relevantes tenha sido eventualmente incompleta; absorve ela, desse modo, necessariamente, tanto as questões que foram discutidas como as que o poderiam ser ${ }^{126}$.

A observância obrigatória da dimensão vinculante da autoridade da coisa julgada representa importante efeito da própria ordem constitucional, que qualifica, dentre diversos princípios dela decorrentes, o principio da segurança jurídica.

Apesar da previsão contida nos $\S \S 13$ e 14 do referido dispositivo processual, no sentido de permitir a modulação de efeitos, "em atenção à segurança jurídica", o fato é que tal norma abriu uma fenda enorme por onde é possível à parte sucumbente na demanda, mormente a Fazenda Pública - com base no art. 535, §5º do CPC/2015 - de arrastar as demandas judiciais por décadas, trazendo uma forte insegurança jurídica para aqueles que têm para si uma sentença favorável do Estado-Juiz.

Dessa forma, as novas normas inseridas no CPC/2015 violam frontalmente os princípios constitucionais da segurança jurídica, da coisa julgada, da proteção da confiança e da própria dignidade da pessoa humana, na medida em que impedem o encerramento do

\footnotetext{
${ }^{126}$ LIEBMAN, Enrico Tulio. "Eficácia e Autoridade da Sentença”, p. 52, tradução de Alfredo Buzaid/Benvindo Aires, 1945, Forense.
} 
processo judicial sem que haja um mínimo de previsibilidade sobre a certeza do direito julgado pelo Estado-Juiz.

Nesse pórtico, importa trazer os ensinamentos de J. J. Gomes Canotilho:

\begin{abstract}
Estes dois princípios - segurança jurídica e protecção da confiança - andam estreitamente associados a ponto de alguns autores considerarem o princípio da protecção de confiança como um subprincípio ou como uma dimensão específica da segurança jurídica. Em geral, considera-se que a segurança jurídica está conexionada com elementos objectivos da ordem jurídica - garantia de estabilidade jurídica, segurança de orientação e realização do direito - enquanto a protecção da confiança se prende mais com as componentes subjectivas da segurança, designadamente a calculabilidade e previsibilidade dos indivíduos em relação aos efeitos jurídicos dos actos dos poderes públicos. A segurança e a protecção da confiança exigem, no fundo: (1) fiabilidade, clareza, racionalidade e transparência dos actos do poder; (2) de forma que em relação a eles o cidadão veja garantida a segurança nas suas disposições pessoais e nos efeitos jurídicos dos seus próprios actos. Deduz-se já que os postulados da segurança jurídica e da protecção da confiança são exigíveis perante 'qualquer acto' de 'qualquer poder' - legislativo, executivo e judicial ${ }^{127}$.
\end{abstract}

Os dispositivos processuais em estudo acabam por abrir a grande possibilidade de existirem processos "eternos" no Judiciário brasileiro, porquanto não há qualquer limitação temporal sobre a eventual declaração de inconstitucionalidade emanada do Supremo Tribunal Federal, visto que, como dito alhures, até mesmo o prazo para o ingresso da ação rescisória passou a ser contado a partir do julgamento emitido por aquela Corte Constitucional, nos termos dos arts. $525, \S 15$ e $535, \S 5^{\circ}$ do CPC/2015.

Vale dizer, com base nas referidas normas processuais, não há qualquer garantia ao jurisdicionado de que a sentença proferida pelo Estado-juiz, mesmo com trânsito em julgado, poderá lhe promover a satisfação com a entrega do bem da vida buscado, haja vista que a qualquer momento, sem que ele tenha sequer conhecimento, o Supremo Tribunal Federal poderá declarar a inconstitucionalidade da norma que subsidiou a sentença em processo oriundo de qualquer Estado do país em sede de controle concentrado, no qual o contexto, a causa de pedir e o pedido possam ser completamente diversos.

Nesse sentido, é o alerta de Araken de Assis:

\begin{abstract}
Aberta a janela, sob o pretexto de observar equivalentes princípios da Carta Política, comprometidos pela indiscutibilidade do provimento judicial, não se revela difícil prever que todas as portas se escancararão às iniciativas do vencido. $\mathrm{O}$ vírus do relativismo contaminará, fatalmente, todo o sistema judiciário. Nenhum veto, 'a priori', barrará o vencido de desafiar e afrontar o resultado precedente de qualquer processo, invocando hipotética ofensa deste ou daquele valor da Constituição. A simples possibilidade de êxito do intento revisionista, sem as peias da rescisória, multiplicará os litígios, nos quais o órgão judiciário de $1^{\text {o }}$ grau decidirá, preliminarmente, se obedece, ou não, ao pronunciamento transitado em julgado do seu Tribunal e até, conforme o caso, do Supremo Tribunal Federal. Tudo
\end{abstract}

${ }^{127}$ CANOTILHO, J. J. Gomes. Direito Constitucional e Teoria da Constituição, p. 250, 1998, Almedina. 
naturalmente justificado pelo respeito obsequioso à Constituição e baseado na volúvel livre convicção do magistrado inferior.

Por tal motivo, mostra-se flagrante o risco de se perder qualquer noção de segurança e de hierarquia judiciária. Ademais, os litígios jamais acabarão, renovando-se, a todo instante, sob o pretexto de ofensa a este ou àquele princípio constitucional. Para combater semelhante desserviço à Nação, urge a intervenção do legislador, com o fito de estabelecer, previamente, as situações em que a eficácia de coisa julgada não opera na desejável e natural extensão e o remédio adequado para retratá-la [...]. Este é o caminho promissor para banir a insegurança do vencedor, a afoiteza ou falta de escrúpulos do vencido e o arbítrio e os casuísmos judiciais ${ }^{128}$.

Ademais, a possibilidade do ingresso da ação rescisória a partir da decisão do STF em sede de controle difuso atenta contra a própria natureza jurídica da coisa julgada, visto que amplia desproporcionalmente e sem um marco temporal seguro o prazo da rescisória, que deveria ser contado, tal qual é engendrado no sistema processual pátrio, a partir da formação da coisa julgada no processo específico no qual se busca a rescisão.

Nesse sentido, assim explicitou José Frederico Marques:

\begin{abstract}
Passando em julgado a sentença ou acórdão, há um julgamento com força de lei entre as partes, a que estas se encontram vinculadas imutavelmente.

Permitido está, no entanto, que se ataque a 'res iudicata' (...), principalmente através de ação rescisória. (...).

Esse prazo é de decadência e seu 'dies a quo' se situa na data em que ocorreu a 'res iudicata' formal. (...).

Decorrido o biênio sem a propositura da rescisória, há coisa 'soberanamente' julgada, o que também se verifica depois de transitada em julgado decisão declarando improcedente a rescisória $^{129}$.
\end{abstract}

Ou seja, após o biênio decadencial transcorrido a partir do trânsito em julgado da decisão, a coisa julgada torna-se soberana, vinculando as partes "imutavelmente".

Aliás, o próprio STF, por diversas oportunidades, defendeu a autoridade da coisa julgada, sem se atentar muito quanto ao quesito de constitucionalidade da decisão, mormente em face do Poder Público. Conforme, por exemplo, o seguinte julgado:

\title{
O CUMPRIMENTO DAS DECISÕES JUDICIAIS IRRECORRÍVEIS IMPÕE-SE AO PODER PÚBLICO COMO OBRIGAÇÃO CONSTITUCIONAL INDERROGÁVEL
}

A exigência de respeito incondicional às decisões judiciais transitadas em julgado traduz imposição constitucional justificada pelo princípio da separação de poderes e fundada nos postulados que informam, em nosso sistema jurídico, a própria concepção de Estado Democrático de Direito.

O dever de cumprir as decisões emanadas do Poder Judiciário, notadamente nos casos em que a condenação judicial tem por destinatário o próprio Poder Público, muito mais do que simples incumbência de ordem processual, representa uma

\footnotetext{
${ }^{128}$ ASSIS, Araken de. Eficácia da Coisa Julgada Inconstitucional”, "in” Revista Jurídica no 301/7-29, 12-13

${ }^{129}$ MARQUES, José Frederico. Manual de Direito Processual Civil”, vol. III/344, item n. 698, $2^{\mathrm{a}}$ ed. $/ 2^{\mathrm{a}}$ tir., 2000, Millennium Editora
} 
incontornável obrigação institucional a que não se pode subtrair o aparelho de Estado, sob pena de grave comprometimento dos princípios consagrados no texto da Constituição da República.

A desobediência a ordem ou a decisão judicial pode gerar, em nosso sistema jurídico, gravíssimas conseqüências, quer no plano penal, quer no âmbito políticoadministrativo (possibilidade de 'impeachment'), quer, ainda, na esfera institucional (decretabilidade de intervenção federal nos Estados-membros ou em Municípios situados em Território Federal, ou de intervenção estadual nos Municípios).

(RTJ 167/6-7, Rel. Min. CELSO DE MELLO, Pleno)

Além disso, a análise da norma ganha maior complexidade, a partir do entendimento firmado no âmbito do STF sobre a ausência de vinculação da "fundamentação" dos precedentes vinculantes, levando à conclusão de que o parâmetro de análise de constitucionalidade envolvendo o precedente se centra exclusivamente no dispositivo das decisões.

Assim, a Suprema Corte brasileira não acolheu a tese da transcendência dos motivos determinantes ${ }^{130}$, somente admitindo que a eficácia de irradiação de suas decisões vinculantes alcance apenas o que ficar escrito em seu dispositivo, deixando de lado a ratio ou os fundamentos de onde se originaram as conclusões, no caso, pela constitucionalidade ou inconstitucionalidade de uma norma.

Com isso, chegamos à possibilidade de que haja a aplicação ilimitada de uma decisão do STF no controle difuso, desconstituindo sentenças transitadas em julgado, sem que haja sequer identidade entre o fundamento do precedente vinculante e a sentença desconstituída.

Todavia, como veremos, os precedentes vinculantes não podem ser vistos sem que haja a imprescindível análise de seus fundamentos e de sua compreensão hermenêutica, a fim de impedir a proliferação de desconstituições injustas de sentenças judiciais e a violação das garantias processuais constitucionais.

\section{PRECEDENTES VINCULANTES, SUA COMPREENSÃO HERMENÊUTICA E A

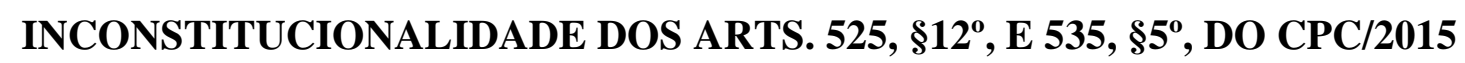

O estudo dos precedentes vinculantes oriundos das Cortes Constitucionais ou de um direito jurisprudencial não pode perder de vista a compreensão do caráter do direito como uma "prática social" de natureza hermenêutica, em que se depura o espírito do agir humanamente num contexto de sociedade, cuja gênese da norma abrange a própria intepretação e aplicação do direito posto, consoante balizas pressupostas.

${ }^{130}$ Rcl 11477 AgR/CE, rel. Min. Marco Aurélio, 29.5.2012 
Dessa forma, os precedentes vinculantes oriundos das decisões do STF em controle difuso de constitucionalidade devem ser aplicados de forma parcimoniosa, sempre buscando a construção argumentativa no bojo de cada processo judicial, cuja sentença transitada em julgado seja atingida pelas normas fixadas nos arts. 525, §12 ${ }^{\circ}$, e 535, §5 , do CPC/2015.

Nos dizeres de Dworkin, a atividade judicial é um processo argumentativo $e$ construtivo, não estando restrito a simples mencanicidades dedutivistas que permeiam parte das vertentes juspositivistas ideológicas.

Não é por acaso que o jurista italiano Gustavo Zagrebelsky ${ }^{131}$ inicia sua obra sobre o caráter fluido do direito e a ductilidade constitucional com a seguinte conclusão: "O que é verdadeiramente fundamental, pelo mero fato de sê-lo, nunca pode ser posto, mas sim sempre pressuposto".

Nesse contexto, a declaração de inconstitucionalidade de uma norma, em controle incidental pelo STF, não pode ser aplicada de forma indistinta, como se norma positivada fosse, aos processos judiciais nos quais se operou o trânsito em julgado, apenas com base no caráter vinculante erga omnes.

É necessário que haja uma contextualização e a perfeita comparação entre os fatos e a ratio decidendi do caso concreto no processo paradigma e o processo em que se busca a desconstituição da coisa julgada, mormente quando se tratar de uma decisão de inconstitucionalidade tomada em sede de controle difuso.

Contudo, tal adequação hermenêutica entre o processo paradigma e o processo cuja decisão estaria viciada de inconstitucionalidade, encontra óbice de ordem prática de aplicação imposta pelo próprio STF, visto que essa Corte Constitucional, como dito anteriormente, entende que em suas decisões não se aplica a teoria da transcendência dos motivos determinantes.

Dito de outa forma, para o STF, o que vincula em suas decisões é apenas a parte dispositiva do julgado, sendo irrelevantes as razões e fundamentos fáticos utilizados para se chegar à conclusão.

O que nos leva à perplexa situação de que, além de haver a possibilidade, ad eternum, da desconstituição da coisa julgada, a "sentença imutável" pode ser modificada até mesmo com base numa decisão tomada em sede de controle difuso de constitucionalidade, cujas razões de decidir sejam completamente distintas.

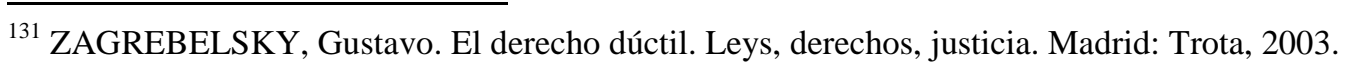


Sob esses aspectos, chega-se à inarredável conclusão de que os arts. 525, §12, e 535, $\S 5^{\circ}$, do CPC/2015, sobretudo no que concerne às decisões de inconstitucionalidade em sede de controle difuso, são materialmente inconstitucionais, por violar diretamente os princípios constitucionais da coisa julgada, da segurança jurídica e da própria duração razoável do processo, visto que existe a possibilidade de que a mesma questão seja debatida durantes anos a fio.

Ademais, em que pese o entendimento do STF nos autos da ADI 3406/RJ, que declarou a mutação constitucional do art. 52, X, da Constituição de 1988 - que conferia ao Senado o papel de atribuir eficácia suspensiva erga omnes às decisões do STF tomadas em controle difuso de constitucionalidade - o fato é que tais dispositivos tambem violam o referido dispositivo constitucional.

Eis a redação do art. 52, X, da Constituição de 1988:

Art. 52. Compete privativamente ao Senado Federal:

$[\ldots]$

$X$ - suspender a execução, no todo ou em parte, de lei declarada inconstitucional por decisão definitiva do Supremo Tribunal Federal;

Nos autos da ADI 3406/RJ, o STF decidiu que o art. 52, X, sofreu uma mutação constitucional em ordem a prever que tal "competência" constitucional deveria ser interpretada apenas como sendo uma competência de ser "informado" da decisão de inconstitucionalidade da Lei, numa intepretação, data venia, visivelmente forçada e contra legem.

Para além dos debates sobre a mutação constitucional do art. 52, X, da CF/88 - que não é o foco da presente obra - o fato é que o Constituinte Originário fixou sim a competência constitucional do Senado, de forma clara e objetiva, de atribuir efeitos erga omnes às decisões do STF em controle de constitucionalidade concreto, suspendendo a execução da Lei em todo o território nacional, talvez já prevendo o necessário respeito à segurança jurídica de terceiros que, porventura, fossem prejudicados por aquela decisão tomada entre as partes de um caso concreto no âmbito do STF.

Vale dizer, o Constituinte Originário entendeu que cabe ao Senado, casa parlamentar onde se dão abertamente debates e discussões de interesse da sociedade civil como um todo, a competência para decidir se confere ou não os efeitos erga omnes às decisões do STF em sede de controle concreto de constitucionalidade, sob uma perspectiva dialética e, por que não dizer, habermasiana na busca democrática da construção de consensos. 
Em que pesem opiniões de peso, como Fredie Didier Jr., que aduz que o STF, ao julgar um processo em sede de controle de constitucionalidade difuso, após a análise da repercussão geral, está na verdade julgando abstratamente a constitucionalidade das normas em debate no caso concreto, é de se entender que as conclusões dos Ministros estão, seguramente, contaminadas pelos fatos e pessoas envolvidas no processo subjacente à questão constitucional.

Assim, os citados dispositivos processuais também violam o disposto no art. 52, X, da Constituição de 1988, uma vez que interferem no próprio debate democrático fixado no referido sistema constitucional, quanto à eficácia das decisões do STF nessas hipóteses, violando a competência constitucional do Senado Federal.

Dessa forma, a desconstituição da coisa julgada, nessas hipóteses do arts. 525, §12, e $535, \S 5^{\circ}$, do CPC/2015 - em especial no que concerne ao julgamento em sede de controle difuso de constitucionalidade pelo STF - poderia acarretar consectários lesivos às relações intersubjetivas e sua estabilidade, e à certeza e segurança jurídica decorrentes do Estado Democrático de Direito como, inclusive, já decidiu o STF em diversos julgados daquela Corte Constitucional $^{132}$.

A desconstituição da "auctoritas rei judicatae", que vem sendo expressamente garantida pela ordem constitucional desde a Constituição de 1934, sem a devida discussão na decisão paradigma do STF e a necessária análise de sua vinculatividade aos demais processos, sem uma averiguação quanto à ratio decidendi, implicará verdadeira afronta ao devido processo legal e à garantia da segurança jurídica, princípio basilar do Estado Democrático Constitucional de Direito.

Apesar disso, o STF, no Recurso Extraordinário 611.503, da Relatoria do Ministro Edson Fachin, julgado no final do ano de 2018, reafirmou que "são constitucionais as disposições normativas do parágrafo único do art. 741 do CPC, do $\S 1^{\circ}$ do art. 475-L, ambos do CPC/73, bem como os correspondentes dispositivos do CPC/15, o art. $525, \S 1^{\circ}$, III e $\S \S 12$ e 14 , o art. $535, \S 5^{\circ}$ \%.

No referido julgado, o STF deixou passar uma grande oportunidade de buscar uma intepretação das normas processuais mais consentânea com o princípio constitucional da coisa julgada, baseando-se unicamente em conceitos abertos e frágeis como a "harmonização".

Desse modo, resta ao intérprete, enquanto não modificado o entendimento do STF, buscar a análise hermenêutica dos precedentes judiciais em sede de controlde difuso de

${ }^{132}$ Por exemplo: RE 554.111/RS - RE 594.350/RS - RE 594.892/RS - RE 594.929/RS - RE 595.565/RS 
constitucionalidade, a fim de impedir a desconstituição indiscriminada de sentenças judiciais transitadas em julgado.

Nesse sentido, Thomas da Rosa de Bustamente bem explicita a tarefa do aplicador do direito na interpretação dos precedentes judiciais:

\begin{abstract}
A atividade do aplicador do Direito, nesse terreno, é uma atividade reconstrutiva, uma atividade de intepretação das decisões judiciais para o fim de aplicá-las como precedentes na solução de casos futuros.(...) Quando passamos da análise reconstrutiva das decisões judiciais - para delas extrair normas - para o problema da determinação do peso das normas jurisprudenciais na argumentação juridica já não estamos apenas descrevendo ou reconstruindo as premissas normativas de uma decisão já tomada por uma autoridade judicial, mas nos encontramos diante da necessidade de decidir acerca da força argumentativa que deve ser atriduida à ratio decidendi que pretendemos utilizar como um elemento de justificação de um caso ainda não solucionado ${ }^{133}$.
\end{abstract}

É de se destacar que, como qualquer decisão judicial, os precedentes vinculantes, em especial aqueles originários das Cortes Constitucionais, estão sujeitos, como está sujeito o próprio texto da Constituição, às fortes influências dos fatores reais de poder, mormente em face das diversas dimensões em que se manifestam os citados precedentes sem seu caráter geral, abstrato e normativo.

Daí que a análise dos fundamentos, historicidade e juridicidade de cada decisão geradora de precedentes vinculantes e do grau de discricionariedade nela inseridos passa a ser fundamental para garantir a sua propria legitimidade, dando-lhe limites e impedindo que descambem para o autoritarismo, arbitrariedades e a expressão de uma ditadura do Judiciário.

\title{
5 CONSIDERAÇÕES FINAIS
}

A inconstitucionalidade material dos arts. $525, \S 12$, e $535, \S 5^{\circ}$, do CPC/2015, quanto à sua aplicação ao controle incidental de constitucionalidade no STF, por violação aos princípios constitucionais da coisa julgada, do devido processo legal e da segurança jurídica é uma conclusão irretorquível.

Isso porque a ampliação desordenada da força normativa do STF, com base em processos subjetivos de constitucionalidade, poderá acarretar justamente a violação dos princípios que os precedentes vinculantes buscam proteger, como a coerência e uniformidade

\footnotetext{
133 BUSTAMANTE, Thomas da Rosa. Teoria do precedente judicial: a justificação e a aplicação das regras jurisprudenciais. São Paulo: Noeses, 2012., p. 329
} 
das decisões jurisdicionais, gerando decisões injustas de desconstituição de sentença devidamente transitadas em julgado há vários anos e, mais que isso, atentando contra os próprios pilares do Estado Democrático de Direito, em especial, o princípio da separação de poderes e dos freios e contrapesos.

Ao refutar a teoria da transcendência dos motivos determinantes de suas decisões, fixando que os seus precedentes somente são observados à luz da tese fixada no dispositivo dos Acórdãos, aquela Corte Suprema acabou por gerar uma incongruência sistêmica, porquanto suas decisões podem levar à desconstituição da coisa julgada em milhares de processos judiciais, apenas com base em um sintético dispositivo que declara a inconstitucionalidade incidental de determinada norma, sem, no entanto, proceder ao devido cotejo de correlação entre o contexto travado nos autos do processo paradigma e o contexto fático, social, normativo e temporal em que estão inseridos cada um dos processos de instâncias inferiores atingidos.

$\mathrm{Na}$ verdade, com este breve estudo, vislumbra-se uma variada gama de possibilidades de violações aos direitos e garantias individuais em face das decisões do STF tomadas no controle difuso de constitucionalidade com a desconstituição da coisa julgada em milhares de processos pretéritos.

Por outro lado, como forma de diminuir o impacto das mudanças trazidas pelas mencionadas novas normas processuais, é de se reafirmar que a desconstituição da coisa julgada em face das decisões em controle difuso de constitucionalidade emanadas do Supremo Tribunal Federal é uma regra que somente pode ser aplicada em relação às decisões cuja coisa julgada tenha se operado após o advento do CPC/2015, em homenagem aos princípios da segurança jurídica e do tempus regit actum.

Destarte, enquanto tais dispositivos - arts. $525, \S 12^{\circ}$, e $535, \S 5^{\circ}$, do $\mathrm{CPC} / 2015$ continuarem vigentes, somente restará aos juízes e as partes lançarem mão da análise dos contornos hermenêuticos dos precedentes vinculantes em sede de controle de constitucionalidade do Supremo Tribunal Federal e dos institutos de superação ou de adequação de precedentes judiciais provenientes do Common Law.

Com efeito, vivenciamos uma nova lógica dos precedentes judiciais no Brasil, em que abstrativização do controle difuso de constitucionalidade ganha preponderância em detrimento dos princípios constitucionais da segurança jurídica e da coisa julgada, numa relativização que poderá gerar inevitáveis conflitos e decisões injustas, na medida em que permite a permanência da litigância ad eternum. 
Talvez ainda esteja cedo para concluir se a opção do STF em retirar a competência do Senado Federal para suspender as normas declaradas incidentalmente inconstitucionais irá trazer bons fluidos ao ordenamento jurídico pátrio, com a dinamização da justiça, levando segurança jurídica e coerência aos julgados, ou se será somente mais um instrumento de concentração de poder político nas mãos dos Ministros do Supremo Tribunal Federal.

O debate está aberto, cabendo aos operadores do direito buscar as balizas necessárias, em especial na hermenêutica jurídica, a fim de conferir os limites que irão legitimar democraticamente a desconstituição das decisões judiciais imutáveis por meio da abstrativização do controle difuso de constitucionalidade no Supremo Tribunal Federal.

\section{REFERENCIAS}

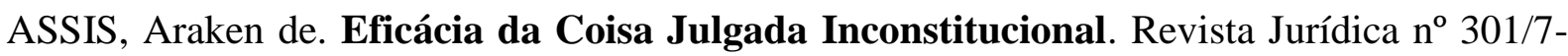
$29,12-13$

BRASIL. Senado Federal. Parecer no 1.624, de 2010. Da Comissão Temporária da Reforma do Código de Processo Civil, sobre o Projeto de Lei do Senado no 166, de 2010, que dispõe sobre a reforma do Código de Processo Civil, e proposições anexadas. Diário do Senado Federal: Brasília, DF, 7 dez. 2010. Disponível em: https://legis.senado.leg.br/sdleggetter/documento?dm=4550666\&ts=1553282790199\&disposition=inline. Acesso em: 11 jul. 2019.

BUSTAMANTE, Thomas da Rosa de. Teoria do precedente judicial: a justificação e a aplicação das regras jurisprudenciais. São Paulo: Noeses, 2012.

CANOTIlHO, J. J. Gomes. Direito Constitucional e Teoria da Constituição. 7. ed. Coimbra: Almedina, 2003.

LIEBMAN, Enrico Tulio. Eficácia e Autoridade da Sentença. Tradução de Alfredo Buzaid e Benvindo Aires. Forense, 1945.

MARQUES, José Frederico. Manual de Direito Processual Civil. São Paulo: Millennium Editora, 2000.

STRECK, Lenio Luiz. Lições de crítica hermenêutica do direito. Porto Alegre: 2. ed. rev. e ampl. Porto Alegre: Livraria do Advogado Editora, 2016. 
ZAGREBELSKY, Gustavo. El derecho dúctil. Leys, derechos, justicia. Madrid: Trota, 2003.

\title{
THE ABSTRACTION OF THE DIFFUSE CONTROL OF CONSTITUTIONALITY \\ WITHIN THE SCOPE OF THE STF AND THE (IN) CONSTITUTIONALITY OF \\ ARTS. 525, §12, 535, §5, OF THE CODE OF CIVIL PROCEDURE OF 2015
}

\begin{abstract}
The new influxes related to the abstractivization of the diffuse control of constitutionality in the jurisprudence of the Federal Supreme Court, combined with the provisions inserted in the new Code of Civil Procedure, especially the norm inscribed in art. 525, paragraph 12, reveal a disproportionate normative force legally fixed to judicial precedents from the Brazilian Constitutional Court that may lead to violation of constitutional procedural guarantees. The present work tries to analyze the unconstitutionality of the new procedural device, at the same time as it seeks to perform an analysis on the possible spectrum of hermeneutical limitations, beyond those traditionally applied, that can be used for a minimal rational control of the grounds of the binding legal precedents stemming from the decisions made in diffuse control of constitutionality by the STF.
\end{abstract}

Keywords: Abstractivization. Diffuse control. Constitutionality. Procedural safeguards. Execution. Hermeneutics. Thing judged. 